\title{
Pemberian Kredit Perbankan dengan Jaminan Hak Cipta
}

\author{
Rayan Reynaldi Setiawan \\ Mahasiswa Magister Hukum Ekonomi Fakultas Hukum Universitas Indonesia \\ Korespondensi: rayanreynaldi1994@gmail.com
}

\begin{abstract}
The main function of Indonesian banking is as a collector and distributor of funds from the community which aims to support the implementation of national development towards improving the welfare of the people. Article 16 (3) of Copyright Law regulates that Copyright as an intangible movable object can be used as an object of fiduciary security. This means, financial institutions, both bank and non-bank, will accept copyright as a credit collateral. This research aims to see the application of credit provision with copyright guarantees and legal remedies that can be taken to protect banks in case of default on loans filed with copyright guarantees. This research is a normative study using documentary studies. The research was found that Copyright Law implicitly states that copyright is an object of fiduciary security, This regulation as stated in Article 16 paragraph (3) requires a detailed explanation, because it relates to a guarantee at the bank itself to produce a refund process from the debtor to the creditor.
\end{abstract}

\section{keywords: Bank, Copyright, Fiduciary Guarantee}

Abstrak. Fungsi utama perbankan Indonesia yaitu sebagai penghimpun dan penyalur dana dari masyarakat yang bertujuan menunjang pelaksanaan pembangunan nasional kearah peningkatan kesejahteraan rakyat. Undang Undang Nomor 28 tahun 2014 tentang Hak Cipta dalam Pasal 16 ayat (3), mengatur bahwa Hak Cipta sebagai benda bergerak tidak berwujud dapat dijadikan sebagai objek jaminan fidusia. Hal ini berarti, lembaga keuangan baik bank maupun non bank akan menerima Hak Cipta sebagai sebuah agunan kredit. Penelitian ini bertujuan untuk melihat penerapan pemberian kredit dengan Jaminan hak cipta dan upaya hukum yang dapat dilakukan untuk melindungi bank jika terjadi wanprestasi atas kredit yang diajukan dengan jaminan Hak Cipta. Penelitian ini merupakan penelitian normatif yang menggunakan studi dokumen. Hasil dari penelitian ini menemukan bahwa dalam Undang-Undang Nomor 28 Tahun 2014 tentang Hak Cipta secara implisit menyebutkan hak cipta sebagai objek jaminan fidusia, Regulasi yang tercantum pada Pasal 16 ayat (3) ini memerlukan penjelasan secara terperinci, dikarenakan berhubungan dengan suatu jaminan pada bank itu sendiri untuk menghasilkan proses pengembalian dana dari debitur kepada kreditur.

Kata Kunci: Perbankan, Hak Cipta, Jaminan Fidusia

\section{PENDAHULUAN}

\section{Latar Belakang}

Salah satu kegiatan usaha pokok bagi bank adalah memberikan kredit. Kredit disalurkan bank kepada masyarakat sesuai dengan fungsi utamanya menghimpun dan menyalurkan dana masyarakat. Dalam pelaksanaan pemberian kredit perbankan tersebut biasanya dikaitkan dengan berbagai persyaratan, antara lain mengenai jumlah maksimal kredit, jangka waktu kredit, tujuan penggunaan kredit, suku bunga kredit, cara penarikan dana kredit, jadwal penulasan kredit dan jaminan kredit.
Pasal 3 dan 4 Undang-Undang Nomor 10 Tahun 1998 tentang Perubahan Atas UndangUndang Nomor 7 Tahun 1992 tentang Perbankan menyebutkan bahwa fungsi utama perbankan Indonesia yaitu sebagai penghimpun dan penyalur dana dari masyarakat yang bertujuan menunjang pelaksanaan pembangunan nasional kearah peningkatan kesejahteraan rakyat.

Sesuai dengan Pasal 1 ayat 11 Undangundang No 10 Tahun 1998 tentang Perbankan, disebutkan Kredit merupakan kegiatan penyediaan tagihan atau uang yang dilakukan berdasarkan kesepakatan tentang pinjam 
meminjam dalam jangka waktu tertentu antara pihak Kreditur atau pihak yang meminjamkan dengan pihak lain yang mewajibkan pihak pemimjam atau debitur untuk melunasi hutangnya dengan pemberian bunga.

Unsur utama pemberian kredit adalah kepercayaan. Kepercayaan merupakan keyakinan kreditur bahwa penerima kredit (debitur) dapat memenuhi segala sesuatu yang telah disepakati di kemudian hari. Untuk memperoleh keyakinan dan kepercayaan tersebut harus sampai pada suatu keyakinan sejauh mana konsep penilaian kredit dapat terpenuhi dengan baik.1 Menurut Peraturan Presiden Nomor 9 Tahun 2009 tentang Lembaga Pembiayaan (selanjutnya disebut Perpres Lembaga Pembiayaan) adalah kegiatan pembiayaan untuk pengadaan barang berdasarkan kebutuhan konsumen dengan pembayaran secara angsuran.

Bank selaku lembaga pembiayaan wajib memperhatikan calon debitur dengan melakukan penilaian terhadap watak, kemampuan, modal, jaminan dan keadaan. Salah satu bentuk pengamanan kredit dengan perjanjian jaminan. Jaminan sebagai lembaga hukum melahirkan asas-asas hukum sebagaimana diatur dalam hukum perdata yang memiliki kedudukan penting dalam dunia ekonomi.

Karakteristik suatu benda yang digunakan sebagai obyek jaminan utang adalah benda yang mempunyai nilai ekonomis dalam artian suatu saat apabila debitur tidak dapat melunasi utangnya benda tersebut dapat menutup utang tersebut, dalam kaitannya dengan hak cipta yang dapat digunakan sebagai hak cipta tentunya mempunyai nilai ekonomis, telah didaftarkan ke Direktorat Jendral Hak Kekayaan Intelektual, dan masih dalam masa perlindungan karena berkaitan dengan nilai keekonimian hak cipta tersebut. Lembaga haminan yang paling memungkinkan dibebankan pada hak cipta sebagai obyek jaminan utang adalah lembaga jaminan fidusia mengingat pada jenis obyek jaminan yang berupa benda bergerak dan mengenai penyerahan benda jaminan. Namun di lain pihak, obyek fidusia adalah benda bergerak berwujud, sedangkan hak cipta adalah benda bergerak tidak berwujud.

Undang Undang Nomor 28 tahun 2014 tentang Hak Cipta dalam Pasal 16 ayat (3), mengatur bahwa Hak Cipta sebagai benda bergerak tidak berwujud dapat dijadikan sebagai objek jaminan fidusia. Hal ini berarti, lembaga keuangan baik bank maupun non bank akan menerima Hak Cipta sebagai sebuah agunan kredit. Pada prakteknya, sampai dengan saat ini, belum ada lembaga keuangan manapun yang menjalankan ketentuan tersebut. Hal ini tentu saja terkait dengan pemberlakuan asas kehati-hatian bank, dimana bank harus mendapatkan kepastian pengembalian dana yang telah dipinjamkan kepada seniman.

\section{Rumusan Masalah}

Artikel ini membahas mengenai bagaimana pemberian kredit dengan hak cipta sebagai jaminan jika dilihat dari Undang Undang No 10 tahun 1998 tentang Perbankan, dan apa upaya hukum yang dapat dilakukan untuk melindungi bank jika terjadi wanprestasi atas kredit yang diajukan dengan jaminan Hak Cipta. Untuk membahas hal tersebut, akan dibahas terlebih dahulu mengenai Hak Cipta sebagai jaminan fidusia dan mekanisme pemberian kredit oleh bank. Tulisan ini juga membahas mengenai tantangan yang muncul terkait pemberian kredit dengan jaminan Hak Cipta beserta saran yang perlu dilakukan untuk menjawab tantangan tersebut.

\section{METODE PENELITIAN}

Metode penelitian yang digunakan untuk menjawab permasalahan dalam artikel ini yaitu dengan menggunakan metode penelitian hukum normatif. Penelitian hukum normatif adalah penelitian yang dilakukan dengan cara meneliti bahan pustaka atau data sekunder belaka. Dalam melakukan penelitian ini, penulis menggunakan metode studi pustaka dengan melakukan studi dokumen terhadap dokumen-dokumen data sekunder yang ada. Adapun data sekunder yang digunakan dalam penelitian ini berupa buku, jurnal, berita dan peraturan perundang-undangan. Dalam penelitian ini, Penulis menggunakan bahan hukum primer. 


\section{HASIL PENELITIAN DAN PEMBAHASAN \\ 1.1. Hak Cipta Sebagai Jaminan Fidusia Hak Cipta}

Hak Cipta menurut ketentuan Pasal 1 ayat (1) UUHC Tahun 2014 adalah "Hak Cipta adalah hak eksklusif pencipta yang timbul secara otomatis berdasarkan prinsip deklaratif setelah suatu ciptaan diwujudkan dalam bentuk nyata tanpa mengurangi pembatasan sesuai dengan ketentuan peraturan perundangundangan".

Prinsip-prinsip dalam Undang-Undang Nomor 28 Tahun 2014 Tentang Hak Cipta tidak lepas tidak lepas dari Madzab hukum alam yang menekankan pada faktor pengguna akal untuk menghormati dan menghargai setiap karya intelektual seseorang. Penghargaan tersebut diberikan karena sebuah ciptaan merupakan hasil pemikiran "Intelektual" yang mengandung nilai ekonomi. Secara sosiologis suatu ciptaan mempunyai manfaat bagi kehidupan manusia sehingga menimbulkan konsepsi harta kekayaan, konsepsi hak dan konsepsi perlindungan hukum. Dengan adanya undang-undang Hak Cipta dapat memberikan kepastian hukum untuk melindungi dan mengembangkan bakatbakat dan kemampuan manusia sehingga dapat mewujudkan karya intelektual yang mempunyai manfaat ekonomi.

\section{Jaminan Fidusia}

Fidusia berasal dari kata fiduciair atau fides, yang artinya kepercayaan,yaitu penyerahan hak milik atas benda secara kepercayaan sebagai jaminan(agunan) bagi pelunasan piutang kreditor. Fidusia sering disebut denganistilah FEO, yang merupakan singkatan dari Fiduciare Eigendom Overdracht.Penyerahan hak milik atas benda ini dimaksudkan hanya sebagai agunan bagipelunasan utang tertentu, di mana memberikan kedudukan yang diutamakankepada penerima fidusia (kreditor) terhadap kreditor-kreditor lainnya.

Pengertian fidusia dinyatakan dalam Undang-Undang No 42 Tahun 1999 Tentang Jaminan Fidusia Pasal 1 angka 1, bahwa :fidusia adalah pengalihan hak kepemilikan suatu benda atas dasarkepercayaan dengan ketentuan bahwa benda yang hak kepemilikannya dialihkan tersebut tetap dalam penguasaan pemilik benda. Sedangkan pengertian jaminan fidusia terdapat dalam Pasal 1 angka 2 UUJF yang menyatakan, bahwa : jaminan fidusia adalah hak jaminan atas benda bergerak baik yang berwujud maupun yang tidak berwujud dan benda tidak bergerak khususnya bangunan yang tidak dapat dibebani hak tanggungan sebagaimana dimaksud dalam Undang-Undang Nomor 4 Tahun 1996tentang Hak Tanggungan yang tetap berada dalam penguasaan pemberi fidusia, sebagai agunan bagi pelunasan utang tertentu, yang memberikan kedudukan yang diutamakan kepada penerima fidusia terhadap kreditorl ainnya.

Pengalihan hak kepemilikan atas benda yang menjadi objek jaminan fidusia seperti tersebut di atas dilakukan dengan cara constitutum possessorium (verklaring van houderschap), artinya pengalihan hak kepemilikan atas suatu benda dengan melanjutkan penguasaan atas benda tersebut yang berakibat bahwa pemberi fidusia seterusnya akan menguasai benda dimaksud untuk kepentingan penerima jaminan fidusia "(Penerima Fidusia)". Pengalihan hak kepemilikan atas suatu benda dengan cara tersebut dikenal dan digunakan secara luas di Perancis sejak abad pertengahan, pengalihan hak kepemilikan tersebut berbeda dari pengalihan hak milik sebagaimana dimaksud dalam pasal 584 jo pasal 612 ayat $1 \mathrm{KUH}$ Perdata, dalam hal jaminan fidusia pengalihan hak kepemilikan dimaksud semata-mata sebagai jaminan/agunan bagi pelunasan utang, bukan untuk seterusnya dimiliki oleh Penerima Fidusia.

Selain itu UU Fidusia juga menegaskan bahwa jaminan fidusia merupakan perjanjian ikutan atau aksesor (accesoir) dari suatu perjanjian pokok22, hal ini berbeda dengan anggapan yang berlaku di Jerman bahwa FEO tidak bersifat aksesor, akibat dari sifat ikutan jaminan fidusia adalah bahwa jaminan fidusia hapus demi hukum bilamana utang yang dijamin dengan jaminan fidusia dihapus.Menurut Tan Kamelo, bahwa asas- 
asas jaminan sebagaimana terdapat dalam UUJF sebagai berikut:

1. kreditur penerima fidusia berkedudukan sebagai kreditur yang diutamakan dari kreditur-kreditur lainnya.

2. jaminan fidusia tetap mengikuti benda yang menjadi obyek jaminan fidusia dalam tangan siapapu benda tersebut berada.

3. jaminan fidusia merupakan perjanjian ikutan yang lazim disebut asas asesoritas

4. jaminan fidusia dapat diletakkan atas hutang yang baru aka nada

5. jaminan fidusia dapat dibebankan pada benda yang aka nada

6. bahwa jaminan fidusia dapat dibebankan pada bangunan/ rumah yang terdapat di atas tanah milik orang lain

7. jaminan fidusia berisikan uraian secara detail terhadap subyek dan obyek jaminan fidusia

8. pemberi jaminan fidusia harus orang yang memiliki kewenangan hukum atas obyek jaminan fidusia

9. jaminan fidusia harus didaftar ke Kantor pendaftaran Fidusia

10. benda yang dijadikan objek jaminan fidusia tidak dapat dimiliki oleh kreditur penerima jaminan fidusia

11. jaminan fidusia memberikan hak prioritas kepada kreditur penerima fidusia yang terlebih dahulu ke kantor fidusia daripada kreditur yang mendaftarkan kemudian

12. pemberi jaminan fidusia yang tetap menguasai benda jaminan harus mempunyai iktikad baik

13. jaminan fidusia mudah dieksekusi.

\subsection{Pemberian Kredit Perbankan Kredit Perbankan}

Bank merupakan badan usaha yang menghimpun dana dari masyarakat dalam bentuk simpanan dan menyalurkan kepada masyarakat dalam bentuk kredit dan atau bentuk-bentuk lainnya dalam rangka meningkatkan taraf hidup rakyat banyak. Oleh karena itu terdapat dua fungsi bank di Indonesia, yaitu menghimpun dana masyarakat dalam bentuk simpanan (funding) dan menyalurkan kembali pada masyarakat dalam bentuk kredit (lending.).
Kredit dari sisi bank merupakan sumber pendapatan yang memberikan kontribusi yang cukup besar bagi pendapatan bank itu sendiri. Untuk memperoleh kredit bank seorang debitur harus melalui beberapa tahapan yaitu tahapan pengajuan aplikasi kredit sampai dengan tahap penerimaan kredit.Sebagai pemberi kredit, bank wajib menetapkan suatu kebijakan agar dapat memelihara keseimbangan untuk memperoleh keuntungan dan menjamin semua kreditnya dapat diselesaikan dengan itikad baik dari debitur.

Kredit dapat digolongkan ke dalam beberapa golongan, diantaranya yaitu:

1. Kredit menurut sifat penggunaannya

a) Kredit konsumtif, kredit ini digunakan untuk memenuhi kebutuhan hidup.

b) Kredit produktif, kredit ini ditujukan untuk keperluan produktif, utility uang dan/ atau barang akan bertambah meningkat. Lain halnya dengan kredit konsumtif tersebut diatas, yang dipergunakan untuk keperluan konsumsi dan karenanya tidak menambah utility uang, melainkan akan dapat menurunkan nilai uang, bila nilai barangnya menurun/merosot.

2. Kredit menurut keperluannya

a) Kredit investasi, kredit ini diberikan oleh bank kepada para nasabahnya untuk keperluan penanaman modal. Kredit tersebut tidak dimaksudkan untuk keperluan perbaikanatau pertambahan barang modal serta fasilitas lainnya yang berhubungan dengan hal itu.

b) Kredit eksploitasi adalah kredit yang diberikan kepada para nasabah untuk keperluan menutup biayabiaya eksploitasi perusahaan secara luas, baik berupa pembelian bahanbahan baku, bahan penolong maupun biaya produksi lainnya. Kredit investasi dan eksploitasi ini pada dasarnya dimaksudkan untuk meningkatkan produksivitas, baik secara kuantitatif maupun kualitatif.

c) Kredit perdagangan, dipergunakan untuk keperluan perdagangan pada umumnya. Dengan kredit ini dapat 
dilakukan pemindahan barang dari suatu tempat ke tempat lainnya. Sehingga dapat membawa peningkatan utility of place dari barang yang bersangkutan.

3. Kredit menurut jangka waktunya

a) Kredit jangka pendek, berjangka waktu selama-lamanya satu tahun.

b) Kredit jangka menengah, berjangka waktu satu sampai tiga tahun.

c) Kredit jangka panjang, berjangka waktu lebih dari tiga tahun.

4. Kredit menurut cara pemakaiannya

a) Kredit dengan uang muka, penarikan kredit dilakukan sekaligus, dalam arti kata maksimum kredit pada waktu penarikan pertama, sepenuhnya dipergunakan oleh nasabah untuk usahanya.

b) Kredit rekening koran, dalam sistem ini, debitur menerima seluruh kreditnya dalam bentuk rekening koran dan kepadanya diberikan blangko cek. Nasabah bebas melakukan penarikanpenarikan kreditnya sesuai dengan yang dibutuhkan untuk usahanya sampai batas maksimum kredit yang ditetapkan. Sedangkan rekening koran pinjamannya diisi menurut besarnya kredit yang ditarik. Penarikan yang melampaui batas maksimum yang telah ditetapkan tidak diizinkan.

5. Kredit menurut jaminannya

a) Kredit tanpa jaminan. Kredit tanpa jaminan bukan berarti tidak ada jaminan sama sekali, melainkan jaminan yang berbentuk bonafiditas dan prospek usaha nasabah tetap diperhatikan dan ditekankan dengan sungguhsungguh dalam pertimbangan kreditnya.

b) Kredit dengan jaminan Kredit ini diberikan pada nasabah yang sanggup menyediakan suatu benda tertentu atau surat berharga atau orang untuk diikatkan sebagai jaminan. Disamping jaminan fisik, bonafiditas dan prospek usaha nasabah tidak terlepas dari perhatian bank dalam rangka pengamanan kredit.

\section{Proses Pemberian Kredit}

Ketentuan Pasal 8 ayat (1) Undang Undang Nomor 10 Tahun 1998 tentang Perbankan merupakan dasar atau landasan bagi bank dalam menyalurkan kreditnya kepada nasabah debitur. Pemberian kredit merupakan salah satu fungsi utama dari bank, maka dalam ketentuan tersebut juga mengandung dan menerapkan prinsip kehati hatian sebagaimana dimaksud dalam ketentuan pasal 2 Undang - Undang Nomor 10 Tahun 1998. Untuk mencegah terjadinya kredit bermasalah dikemudian hari, penilaian suatu bank untuk memberikan persetujuan terhadap suatu permohonan kredit dilakukan dengan berpedoman kepada Formula 4P dan Formula 5C. Formula 4P dapat diuraikan sebagai berikut:

a) Personality

Pihak bank mencari data secara lengkap mengenai kepribadian si pemohon kredit, antara lain mengenai riwayat hidupnya, pengalamannya dalam berusaha, pergaulan dalam masyarakat, dan lain - lain. Hal ini diperlukan untuk menentukan persetujuan kredit yang diajukan oleh pemohon kredit.

b) Purpose

Selain mengenai kepribadian dari pemohon kredit, bank juga harus mencari data tentang tujuan atau penggunaan kerdit tersebut sesuai line of business kredit bank yang bersangkutan.

c) Prospect

Bank harus melakukan analisis secara cermat dan mendalam tentang bentuk usaha yang akan dilakukan oleh pemohon kredit. Misalnya, apakah usaha yang dijalankan oleh pemohon kredit mempunyai prospek di kemudian hari ditinjau dari aspek ekonomi dan kebutuhan masyarakat.

d) Payment

berkaitan dengan penyaluran kredit, bank harus mengetahui dengan jelas mengenai kemampuan dari permohonan dalam jumlah dan jangka waktu yang ditentukan.

Mengenai Formula 5C dapat diuraikan sebagai berikut: 


\section{a) Character}

Calon nasabah debitur memiliki watak, moral, dan sifat - sifat pribadi yang baik. Penilaian terhadap karakter ini dilakukan untuk mengetahui tingkat kejujuran, integritas, dan kemauan dari calon nasabah debitur untuk memenuhi kewajiban dan menjalankan usahanya. Informasi ini dapat diperoleh oleh bank melalui riwayat hidup, riwayat usaha, dan informasi dari usaha usaha yang sejenis.

b) Capacity

maksud dari capacity adalah kemampuan calon nasabah debitur untuk mengelola kegiatan usahanya dan mampu melihat prospektif masa depan, sehinga usahanya dakan dapat berjalan dengan baik dan memberikan keuntungan, yang menjamin bahwa ia mampu melunasi utang kreditnya dalam jumlah dan jangka waktu yang telah ditentukan. Pengukuran kemampuan ini dapat dilakukan dengan berbagai pendekatan, misalnya pendekatan materiil, yaitu melakukan penilaian terhadap keadaan neraca laporan rugi laba, dan arus kas usaha dari beberapa tahun terakhir. Melalui pendekatan ini, tentu dapat diketahui pula mengenai tingka solvabilitas, likuiditas, dan rentabilitas usaha serta tingka risikonya.

c) Capital

Bank harus terlebih dahulu melakukan penelitian terhadap modal yang dimiliki oleh pemohon kredit. Penyelidikan ini tidaklah semata - mata didasarkan pada besar kecilnya modal, akan tetapi lebih difokuskan kepada bagimana distribusi modal ditempatkan oleh pengusaha tersebut, sehingga segala sumber yang telah ada dapat berjalan secara efektif.

d) Collateral

Collateral adalah jaminan untuk persetujuan pemberian kredit yang merupakan sarana pengaman atas risiko yang mungkin terjadi atas wanprestasi nasabah debitur di kemudian hari, misalnya terjadi kredit macet. Jaminan ini diharapkan mampu melunasi sisa utang kredit baik utang pokok maupun bunganya.

e) Condition of economy
Bahwa dalam pemberian kredit oleh bank, kondisi ekonomi secara umum dan kondisi sektor usaha pemohon kredit perlu memperoleh perhatian dari bank untuk memperkecil risiko yang mungkin terjadi yang diakibatkan oleh kondisi ekonomi tersebut.

Untuk memperoleh kredit, calon debitur diharuskan terlebih dahulu mengajukan permohonan kredit. Prosedur pemberian kredit pada tahap awal yang harus ditangani oleh pihak bank, yaitu:

1. Tahap permohonan kredit: Permohonan baru untuk mendapatkan suatu fasilitas kredit, permohonan tambahan suatu kredit yang sedang berjalan, permohonan perpanjangan atau pembaharuan masa laku kredit yang telah berakhir jangka waktunya, permohonanpermohonan lainnya untuk perubahan syarat-syarat fasilitas kredit yang sedang berjalan.

2. Berkas permohonan kredit: Surat-surat permohonan nasabah yang ditandatangani secara lengkap dan sah, daftar isian yang disediakan oleh bank dan diisi secara lengkap oleh nasabah, daftar lampiran lainnya yang diperlukan menurut jenis fasilitas kredit.

3. Pencatatan, setiap surat permohonan kredit yang diterima harus dicatat dalam register khusus yang disediakan.

4. Kelengkapan dan berkas permohonan, permohonan dinyatakan lengkap bila telah memenuhi persyaratan yang ditentukan.

5. Formulir daftar isian permohonan kredit, bank menggunakan daftar isian permohonan kredit yang harus diisi oleh nasabah, formulir-formulir neraca, daftar rugi atau laba.

\section{Pemberian Kredit dengan Jaminan Hak Cipta}

Di dalam Hak Cipta terkandung dua macam hak yaitu hak ekonomi dan hak moral. Hak ekonomi itu sendiri merupakan hak eksklusif Pencipta atau Pemegang Hak Cipta untuk mendapatkan manfaat ekonomi atas Ciptaan. Hak ekonomi yang terkandung di dalam Undang - Undang tentang Hak CIpta, meliputi hak untuk Penggandaan Ciptaan dalam segala bentuknya, penerjemahan Ciptaan, 
pengadaptasian, pengaransemenan, atau pentransformasian Ciptaan, Pendistribusian Ciptaan atau salinannya, pertunjukan Ciptaan, Pengumuman Ciptaan, Komunikasi Ciptaan, dan penyewaan Ciptaan.

Di dalam Undang-Undang Nomor 28 Tahun 2014 tentang Hak Cipta secara implisit menyebutkan hak cipta sebagai objek jaminan fidusia, pernyataan ini terdapat pada Pasal 16 ayat (3). Dalam pasal tersebut tidak secara seutuhnya bank secara mudah memberikan suatu kreditnya. Regulasi yang tercantum pada Pasal 16 ayat (3) ini memerlukan penjelasan secara terperinci. Dikarenakan berhubungan dengan suatu jaminan pada bank itu sendiri untuk menghasilkan proses pengembalian dana dari debitur kepada kreditur. Proses pinjaman kredit dengan objek jaminan hak cipta secara umum tidak terlepas atas dasar nilai suatu karya cipta tersebut. Secara luas, bank dapat memberikan pinjaman kepada debitur dengan catatan bahwa debitur memberikan jaminan atas pinjaman tersebut, dalam hal ini berapa nilai hak cipta yang dapat di appraisal.

Pasal 2 Undang-Undang Nomor 10 Tahun 1998 tentang Perubahan Atas Undang-Undang Nomor 7 Tahun 1992 tentang Perbankan, telah menyatakan tegas bahwa perbankan Indonesia dalam melakukan usahanya berdasarkan demokrasi ekonomi dengan menggunakan prinsip kehati-hatian, dan merujuk pada Peraturan Bank Indonesia (PBI) No. 9/6/PBI/2007. Pasal 46 PBI No. 9/6/ PBI/2007 dinyatakan bahwa jenis agunan kredit adalah sebagai berikut:

(a) surat berharga dan saham yang aktif diperdagangkan di bursa efek di Indonesia atau memiliki peringkat investasi dan diikat secara gadai;

(b) tanah, gedung dan rumah tinggal yang diikat dengan hak tanggungan;

(c) mesin yang merupakan satu kesatuan dengan tanah dan diikat dengan hak tanggungan;

(d) pesawat udara atau kapal laut dengan ukuran di atas dua puluh meter kubik yang diikat dengan hipotik;

(e) kendaraan bermotor dan persediaan yang diikat secara fidusia; dan/atau (f) resi gudang yang diikat dengan hak jaminan atas resi gudang.

Dengan demikian, menjadi suatu hal yang wajar ketika perbankan belum dapat menerima hak cipta sebagai objek jaminan utang. Dikarenakan dalam memberikan bantuan pinjaman kredit kepada debitur, pihak bank perlu menerapkan 5 (lima) prinsip C's yakni character (watak, kepribadian), capital (modal), collateral (pinjaman), capacity (kemampuan), dan condition of economic (kondisi ekonomi).

\subsection{Tantangan dalam Penerapan Hak Cipta sebagai Jaminan Kredit Perbankan}

Tantangan yang dihadapi jika ingin menjadikan kekayaan intelektual sebagai jaminan fidusia adalah masih banyaknya pemangku kepentingan yang tidak memiliki pemahaman yang baik mengenai sistem kekayaan intelektual, termasuk profesi notaris. Selain itu masih banyak pemangku kepentingan yang tidak mengetahui bagaimana melakukan valuasi terhadap kekayaan intelektual. Kedua hal ini tentu saja selain peraturan di bidang perbankan yang tidak menyebutkan secara tegas bahwa kekayaan intelektual dapat dijadikan obyek jaminan.

Salah satu syarat yang harus dipenuhi sebelum kekayaan intelektual dijadikan jaminan fidusia adalah harus ada nilai ekonomis. Nilai ekonomis ini harus dinilai menggunakan parameter dan mekanisme yang jelas. Penilaian inilah yang bisa menjadi dasar bagi lembaga keuangan untuk 'menyetujui' hak cipta sebagai objek jaminan fidusia.

Untuk menentukan nilai ekonomis sebuah kekayaan intelektual, diperlukan adanya profesi jasa penilai yang kompeten untuk menghitung valuasi kekayaan intelektual. Selama ini sudah ada profesi penilai publik (appraiser) yang secara profesional menjalankan fungsi-fungsi penilaian. Menurut Sabartua, untuk menjawab kebutuhan terhadap penilai HKI, bisa dilakukan dengan jalan menambah kompetensi appraiser yang telah ada atau mendirikan lembaga sertifikasi profesi baru dengan kekhususan penilai kekayaan intelektual. 
Perihal eksekusi jaminan fidusia berupa hak cipta apabila terjadi ingkar janji (wanprestatie), Hak Cipta diatur sebagai objek jaminan fidusia yang berarti adanya pengakuan bahwa hak cipta memiliki nilai ekonomi yang dapat digunakan sebagai pelunansan utang. Nilai ekonomi dari hak cipta dapat dilihat dari reputasi yang dimiliki oleh hak cipta tersebut. Semakin baik reputasinya maka akan semakin tinggi nilai ekonominya.

Sebelum hak cipta diajukan sebagai objek jaminan fidusia. Hak cipta tersebut harus sudah didaftarkan di Direktorat Jendral Kekayaan Intelektual, dibuktikan dengan sertifikat hak cipta yang telah diterbitkan oleh Ditjen HKI sebagai lembaga yang berwenang untuk hal itu. Kemudian, Hak cipta harus memenuhi unsur secure dan marketable, artinya hak cipta tersebut dapat diberlakukan cara penghitungan nilai ekonominya oleh lembaga perbankan dengan menggunakan teori ekonomi yang telah diuraikan pada pembahasan di atas, sebagai acuannya untuk selanjutnya dinilai besaran nilai ekonomi pada hak cipta tersebut.

\section{KESIMPULAN}

Sebelum hak cipta diajukan sebagai objek jaminan fidusia. Hak cipta tersebut harus sudah didaftarkan di Direktorat Jendral Kekayaan Intelektual, dibuktikan dengan sertifikat hak cipta yang telah diterbitkan oleh Ditjen HKI sebagai lembaga yang berwenang untuk hal itu. Kemudian, Hak cipta harus memenuhi unsur secure dan marketable, artinya hak cipta tersebut dapat diberlakukan cara penghitungan nilai ekonominya oleh lembaga perbankan dengan menggunakan teori ekonomi yang telah diuraikan pada pembahasan di atas, sebagai acuannya untuk selanjutnya dinilai besaran nilai ekonomi pada hak cipta tersebut.

Di dalam Undang-Undang Nomor 28 Tahun 2014 tentang Hak Cipta secara implisit menyebutkan hak cipta sebagai objek jaminan fidusia, pernyataan ini terdapat pada Pasal 16 ayat (3). Dalam pasal tersebut tidak secara seutuhnya bank secara mudah memberikan suatu kreditnya. Regulasi yang tercantum pada Pasal 16 ayat (3) ini memerlukan penjelasan secara terperinci. Dikarenakan berhubungan dengan suatu jaminan pada bank itu sendiri untuk menghasilkan proses pengembalian dana dari debitur kepada kreditur. Proses pinjaman kredit dengan objek jaminan hak cipta secara umum tidak terlepas atas dasar nilai suatu karya cipta tersebut. Secara luas, bank dapat memberikan pinjaman kepada debitur dengan catatan bahwa debitur memberikan jaminan atas pinjaman tersebut, dalam hal ini berapa nilai hak cipta yang dapat di appraisal.

Pasal 2 Undang-Undang Nomor 10 Tahun 1998 tentang Perubahan Atas UndangUndang Nomor 7 Tahun 1992 tentang Perbankan, telah menyatakan tegas bahwa perbankan Indonesia dalam melakukan usahanya berdasarkan demokrasi ekonomi dengan menggunakan prinsip kehati-hatian. Merujuk pada Peraturan Bank Indonesia (PBI) No. 9/6/PBI/2007, jenis agunan kredi adalah (a) surat berharga dan saham yang aktif diperdagangkan di bursa efek di Indonesia atau memiliki peringkat investasi dan diikat secara gadai; (b) tanah, gedung dan rumah tinggal yang diikat dengan hak tanggungan; (c) mesin yang merupakan satu kesatuan dengan tanah dan diikat dengan hak tanggungan; (d) pesawat udara atau kapal laut dengan ukuran di atas dua puluh meter kubik yang diikat dengan hipotik; (e) kendaraan bermotor dan persediaan yang diikat secara fidusia; dan/atau (f) resi gudang yang diikat dengan hak jaminan atas resi gudang.

Dengan demikian, menjadi suatu hal yang wajar ketika perbankan belum dapat menerima hak cipta sebagai objek jaminan utang. Dikarenakan dalam memberikan bantuan pinjaman kredit kepada debitur, pihak bank perlu menerapkan 5 (lima) prinsip C's yakni character (watak, kepribadian), capital (modal), collateral (pinjaman), capacity (kemampuan), dan condition of economic (kondisi ekonomi).

Perlu dibuat peraturan pelaksanaan dalam praktik hak cipta sebagai objek jaminan di masa depan dengan tetap memberdayakan DJKI sebagai appraisal yang dapat memberian kepastian hukum bagi perbankan dalam pemberian kredit dengan jaminan hak cipta. 


\section{DAFTAR PUSTAKA}

Kamelo, Tan Kamelo. Hukum Jaminan Fidusia; Suatu Kebtuhan yang didambakan. Bandung: PT. Alumni, 2006.

Usman, Rachmadi. Hukum Kebendaan. Jakarta : Raja Grafindo Persada, 2011.

Widiyono, Try. Agunan Kredit dalam Financial Engineering. Bogor : Ghalia Indonesia, 2009.

Christy, Ferry Gunawan, et al. "Hak Cipta sebaga jaminan kredit perbankan dalam pembangunan perekonomian Indonesia.", Jurnal Legislasi Indonesia Vol 17 No 3 (September 2020).

Handayani, Widya Marthauli. "Keberlakuan hukum hak cipta sebagai objek jaminan fidusia berdasarkan Undang - Undang Nomor 28 tahun 2014 tentang Hak Cipta.", Jurnal Legislasi Indonesia Vol 16 No 2 (Juni 2019).

Latifiniani, Dian Latifiani. "Tinjauan yuridis analisa pemberian kredit usaha sebagai upaya preventif timbulnya kredit macet.", Pandecta Vol 8 No 2 (Juli 2013)

Rufaida, Khifni Kafa dan Rian Sacipto. "TInjauan Hukum Terhadap Eksekusi Objek Jaminan Fidusia Tanpa Titel Eksekutorial Yang Sah", Refleksi Hukum Jurnal Ilmu Hukum Vol 4 No 1 (Oktober 2019)

Saroinsong, Andrew Nathanael Saroinsong. "Fungsi bank dalam sistem penyaluran kredit perbankan.", Lex Privatum Vol 2 No 3 (Agustus - Oktober 2014)

Setianingrum, Reni Budi. "Mekanisme Penentuan Nilai Ekonomis dan Pengikatan Hak Cipta Sebagai Objek Jaminan Fidusia", Jurnal Media Hukum Vol 23 No 3 (Desember 2016)

Ulinhua, Lutfi. "Penggunaan Hak cipta sebagai objek jaminan fidusia", Journal of private and commercial law Vol 1 No 1, (November 2017).

Anwar, Moh Anwar. Perlindungan hukum terhadap kreditur dalam perjanjian kredit dengan jaminan hak tanggungan menurut undang - undang No 4 Tahun 1996 ,
$<$ https://media.neliti.com/media/publica tions/37185-ID-perlindungan-hukumterhadap-kreditur-dalam-perjanjiankredit-dengan-jaminan-hak.pdf > diakses 7 Januari 2021

Dhilon, Kennie. Tinjauan yuridis terhadap pemberian kredit bank dengan jaminan personal guarantee, < https://media.neliti.com/media/publicati ons/14709-ID-tinjauan-yuridisterhadap-pemberian-kredit-bankdengan-jaminan-personal-guarante.pdf $>$ diakses 7 Januari 2021

Huzaini, Moh. Dani Pratama. Profesi yang dibutuhkan jika kekayaan intelektual jadi objek Jaminan Fidusia, < https://www.hukumonline.com/berita/ba ca/lt5bd1d4ff1b6cd/profesi-inidibutuhkan-jika-kekayaan-intelektualjadi-objek-jaminan-fidusia/> diakses 7 Januari 2021

Yustisia, Astika Rahma, Iwan Permadi, Itta Andrijani,. Perlindungan hukum bagi bank dalam penyelesaian kredit karena wanprestasi melalui subrogasi, $<$ https://media.neliti.com/media/publica tions/114525-ID-perlindungan-hukumbagi-bank-dalam-penye.pdf>, diakses 7 Januari 2021

Pardede, Marulak. Implementasi Jaminan Fidusia dalam Pemberian Kredit di Indonesia, https://bphn.go.id/data/documents/imple mentasi_jaminan_fidusia_dalam_pembe rian_kredit_di_indonesia..pdf $>$, diakses 7 Januari 2021

Indonesia, Undang - Undang Nomor 42 Tahun 1999 tentang Jaminan Fidusia, LN Pasal 1 Undang-Undang nomor 42 Tahun 1999 tentang Jaminan Fidusia, Lembaran Negara Republik Indonesia (LNRI) Tahun 1999 Nomor 168

Indonesia, Undang - Undang Nomor 42 Tahun 1999 tentang Jaminan Fidusia, LN Pasal 1 Undang-Undang nomor 42 Tahun 1999 tentang Jaminan Fidusia, Lembaran Negara Republik Indonesia (LNRI) Tahun 1999 Nomor 168 
Indonesia, Undang - Undang tentang Hak Cipta, UU No 28 Tahun 2014, LN No. 266 Tahun 2014

Primadewi, Winnie Fauzia. "Tinjauan yuridis terhadap pemberian kredit tanpa agunan untuk perorangan ( Studi kasus pada Bank Mandiri).". Tesis Universitas Indonesia, 2012. 